\title{
THE INFLUENCE OF PAST LAND-USE AND ENVIRONMENTAL FACTORS ON GRASSLAND SPECIES DIVERSITY
}

\author{
ZARZYCKI, J. - BEDLA, D. \\ University of Agriculture in Kraków \\ Department of Ecology, Climatology and Air Protection \\ al. Mickiewicza 24/28, 30-059 Kraków, Poland \\ *Corresponding autor \\ d.bedla@ur.krakow.pl; phone: +48-126-624-013 \\ (Received $3^{\text {rd }}$ Apr 2017; accepted $2^{\text {nd }}$ Jun 2017)
}

\begin{abstract}
Mountain grasslands are among the most species-rich plant communities in Europe. This is due to the large variability of abiotic conditions and ways of management. However, a significant change in the rural economy has taken place in recent decades. Some grasslands have become forested, while others have been overgrown as a result of succession. Fodder for domestic animals is produced on grasslands created on former arable land. The aim of this study was to estimate the effect of topographic factors (altitude, slope, exposure) and land use (grassland, arable land) in the mid-nineteenth century and the 1930s on the present biodiversity of mountain grasslands. The study was carried out in the basin of the Łomniczanka and Wierchomlanka Rivers in the Beskid Sądecki (Polish Carpathians). A total of 73 phytosociological relevés in an altitude gradient ranging from 660 to $1,060 \mathrm{~m}$ a.s.l were made. Past land use was determined on the basis of archival cadastral and topographic maps. The altitude above sea level was the main factor influencing the botanical composition of vegetation. No difference was observed in species composition depending on past land use. The results show the crucial role of altitude in determining the species composition of mountain meadows.
\end{abstract}

Keywords: semi-natural grasslands, grasslands management, species diversity, historical land use

\section{Introduction}

Many habitats, such as semi-natural grasslands, are associated with the centurieslong human activity. The long-term effects of mowing, grazing and fertilization has enabled the emergence of plant communities with numerous species occurring exclusively in these habitats. Mountain grasslands used in a traditional, extensive manner are particularly valuable. These are among the most species-diverse plant communities in the world (Wilson et al., 2012; Chytrý et al., 2015). Grassland communities are also associated with invertebrate species, particularly arthropods (Schaffers et al., 2008). Research also shows that an open landscape is essential for numerous bird species (Siramia et al., 2008; Shi et al., 2014).

The existence of such species-rich communities is the result of the interaction of abiotic habitat factors and extensive use. These communities are found in places with low fertility, which prevents dominance by few highly competitive species, as in fertilized grasslands. On the one hand agricultural production is intensified, while on the other hand marginal areas are no longer being used (Strijker, 2005). Both of these factors lead to a decline in biological diversity and the disappearance of many rare species, which usually have a narrow ecological amplitude (Ellenberg, 1985; Cousins et al., 2015).

In the Polish Carpathian Mountains the problem of abandonment of agricultural land is particularly acute. At the start of the $20^{\text {th }}$ century arable land still dominated the landscape up to an altitude of 1,000 m a.s.l. (Bielecka, 1969) and grasslands occupied 
higher areas or other places that were unsuitable as cropland. In recent decades most former grasslands have become afforested or spontaneous forest succession is taking place on them (Bucała, 2014; Kolecka et al., 2015; Morzyniec et al., 2015). At the same time, arable land has been transformed into grassland, although its total area has not decreased (Twardy, 2008). The grassland communities arising in this manner are usually characterized by lower species diversity (Cousins and Eriksson, 2002).

In mountainous areas the current state of grassland communities is influenced by the high degree of variation in topographic factors such as: altitude a.s.l., exposure, inclination, and soil fertility and moisture. These factors usually act together and it is usually difficult to single out the ones with the greatest effect (Janišová et al., 2010; Klimek et al., 2008). Botanical composition is also linked to the process of immigration of species from other grassland areas and their adaptation to habitat conditions and management. Immigration processes of grassland species, in the case of areas isolated from sources of diaspores, may last a long time. This is most likely why 'old' grasslands with a long, uninterrupted history of use are usually richest in species and thus the most ecologically valuable (Reitalu et al., 2010; Pitkänen et al., 2016). The main questions posed in the study were as follows: (i) what is the main factor responsible for the species composition of grassland communities in mountainous areas? (ii) Do grasslands formed on former arable land differ in species composition from those situated in places that were never used to grow crops?

\section{Materials and methods}

The study was carried out on clearings located in the Pasmo Jaworzyny mountain range (catchment of the Lomniczanka and Wierchomlanka Rivers), which is part of Beskid Sądecki (Western Carpathians) in the forest zone, in an altitude range of 600 $1000 \mathrm{~m}$ a.s.l. (Figure 1). Bedrock of the Jaworzyna mountain range is composed of flysch sandstones and shales. The soil of all the plots were Haplic Cambisol (Dystric).

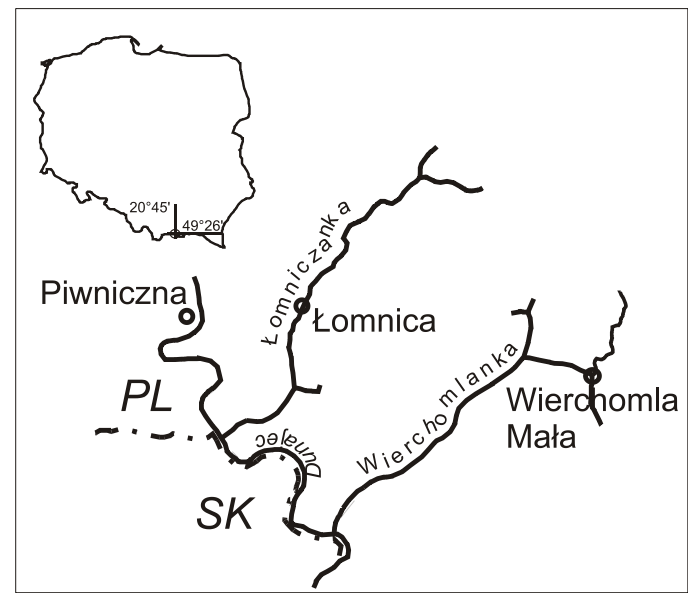

Figure 1. Localization of research area

In 200973 phytosociological relevés with an area of $100 \mathrm{~m}^{2}$ were made; a list of plant species was compiled and their coverage were estimated on the five-point scale (Braun-Blanquet, 1964). Species names were taken after Mirek et al. (2002). In each 
place basic topographic parameters were determined: altitude a.s.l., inclination, and exposure. The values for exposure were transformed using trigonometric functions (Roberts, 1986) to create two new variables: northness $=\cos$ (exsposure in degrees) and eastness $=\sin$ (exsposure in degrees). Cartographic materials were used to determine the type of land use (grassland or arable land) in the mid-nineteenth century, the 1930s and the 1980s. The analysis of past land use was based on Austrian cadastral maps from 1846, a Military Geographical Institute map from 1936 and topographic maps published by the Surveyor General of Poland from 1988. Habitat conditions were evaluated indirectly on the basis of unweighted means of Ellenberg's indicator values (Ellenberg et al., 1992). These were calculated for each relevé for nutrients (N), temperature (T) and soil reaction (R) using JUICE software (Tichý, 2002).

Classification of the phytosociological relevés was based on the similarity of species composition using a modification of TWINSPAN (Roleček et al., 2002). Association of species to vegetation units and statistical significance at $p<0.05$ (Fisher test) was calculated with JUICE (Tichý, 2002). Syntaxonomic system by Matuszkiewicz (2001) was applied. The ordination analyses were carried out using CANOCO ver. 4.5 software (ter Braak and Smilauer, 2002). In detrended correspondence analysis (DCA) the length of the gradient was 3.6 of the standard deviation and canonical correspondence analysis (CCA) was used to test the effect of topographical factors and use on species composition. Statistical significance was determined by a Monte Carlo permutation test.

\section{Results}

Analysis of the phytosociological relevés allowed them to be classified into three main plant communities, forming visible groups with respect to the first DCA axis (Figure 2A):

Class: Vaccinio-Piceetea Br.-Bl. 1939

Order: Vaccinio-Piceetalia Br.-B1. 1939

Alliance: Piceion abietis Pawł. et al.1928

1. Community: Vaccinium myrtillus

Class: Nardo-Callunetea Prsg 1949

Order: Nardetalia Prsg 1949

Alliance: Eu-Nardion Br.-B1. 1926 em. Oberd. 1959

2. Association: Hieracio-Nardetum Kornaś 1955 n.n.

Class: Molinio-Arrhenatheretea R.Tx. 1937

Order: Arrhenatheretalia Pawł. 1928

Alliance: Arrhenatherion elatioris (Br.-B1. 1925) W.Koch 1926

3. Association: Gladiolo-Agrostietum capillaris (Br.-Bl. 1931) Pawł. et Wal. 1949

The Vaccinium myrtillus community, apart from a large share of this species, was characterized by a substantial share in the area cover of species characteristic of HieracioNardetum association: Nardus stricta, Potentilla erecta, Deschampsia caespitosa and herbaceous species: Hypericum maculatum and Luzula luzuloides (Table 1).

This community usually constitutes a stage of overgrowth of unused grasslands and pastures. The number of species in the phytosociological relevé ranged from 7 to 22 (on average 14.1). This community is found in clearings in the upper part of the massif at altitudes from $880 \mathrm{~m}$ a.s.l. to at $1060 \mathrm{~m}$ a.s.l. (Table 2). 


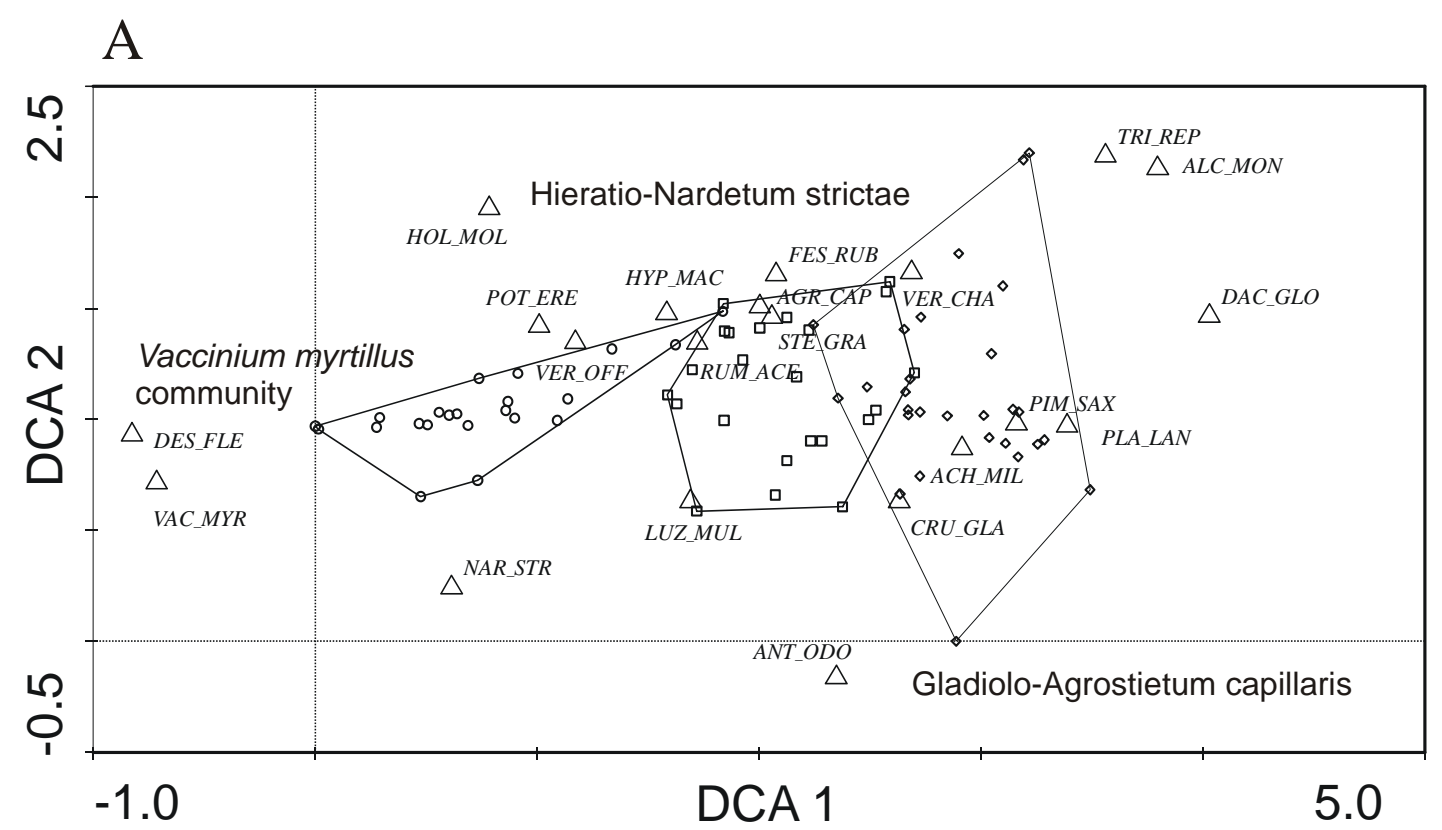

Relevé classification:

$\diamond$ - Gladiolo-Agrostietum capillaris; 口 - Hieratio-Nardetum strictae; o - Vaccinium myrtillus community

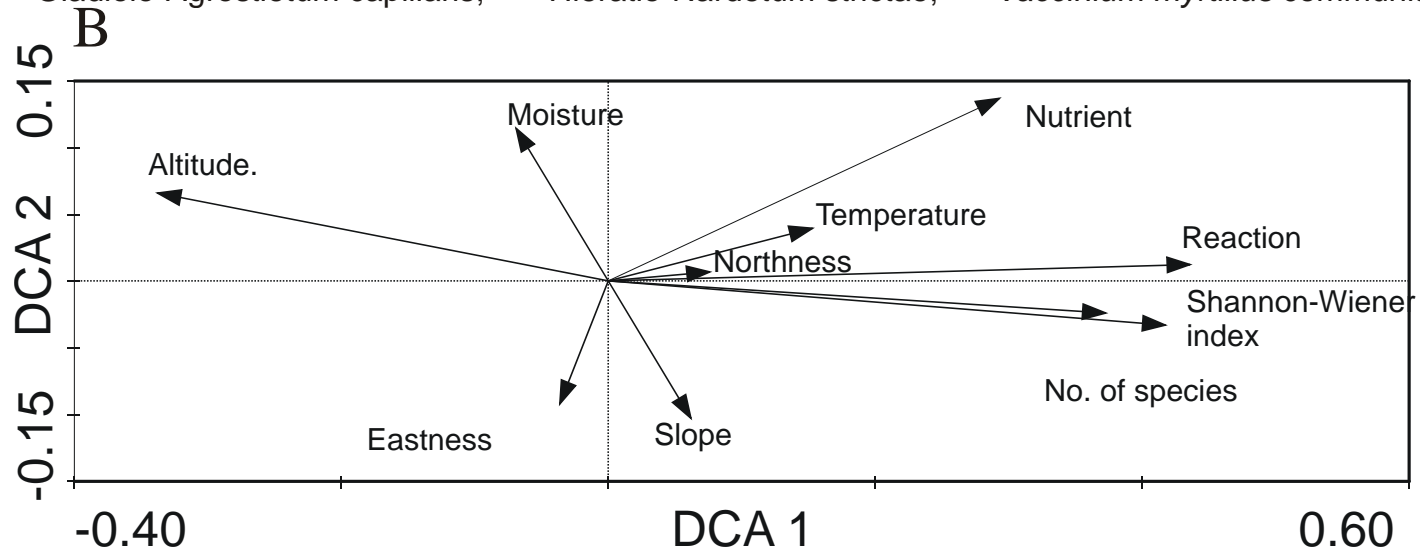

Figure 2. Ordination diagram (DCA) of the whole data set (eigenvalue of I axis 0.463, II axis 0.127; the length of the main axis gradient is 3.64). A - ordination of phytosociological relevés and species (only species with the highest weight has been presented); $B$ - effect of environmental variables. Species names abbreviation: ACH_MIL - Achillea millefolium, ALC_MON - Alchemilla monticola, ANT_ODO Antoxanthum odoratum, CRU_GLA - Cruciata glabra, DAC_GLO - Dactylis glomerata, DES_FLE - Deschampsia flexuosa, FES_RUB - Festuca rubra, HOL_MOL - Holcus mollis, HYP_MAC - Hypericum maculatum, LUZ_MUL - Luzula multiflora, NAR_STR - Nardus stricta, PIM_SAX - Pimpinella saxifraga, PLA_LAN - Plantago lanceolata, POT_ERE Potentilla erecta, RUM_ACE - Rumex acetosa, STE_GRA - Stelaria graminea, TRI_REP Trifolium repens, VAC_MYR - Vaccinium myrtillus, VER_CHA - Veronica chamaedrys, VER_OFF - Veronica officinalis 
Table 1. Species associated with vegetation units (phi indicator for species with statistical significance $p<0.05$ Fisher test). Only species with constancy $>60 \%$ were shown

\begin{tabular}{llll}
\hline \multicolumn{1}{c}{ Species } & $\begin{array}{c}\text { Vegetation unit } \\
\text { Vaccinium myrtillus } \\
\text { community }\end{array}$ & $\begin{array}{l}\text { Hieracio-Nardetum } \\
\text { association }\end{array}$ & $\begin{array}{l}\text { Gladiolo-Agrostietum } \\
\text { association }\end{array}$ \\
\hline Deschampsia flexuosa & 80.0 & --- & --- \\
Vaccinium myrtillus & 62.4 & --- & --- \\
Nardus stricta & 20.9 & 12.7 & --- \\
Holcus mollis & 18.6 & 13.7 & --- \\
Veronica officinalis & 0.9 & 28.7 & --- \\
Dianthus deltoides & --- & 34.6 & 17.9 \\
Stellaria graminea & --- & 31.6 & 20.9 \\
Cruciata glabra & --- & 30.6 & 31.0 \\
Campanula patula & --- & 23.4 & 26.0 \\
Veronica chamaedrys & --- & 51.0 & 40.3 \\
Festuca rubra & --- & 11.4 & 14.6 \\
Agrostis capilaris & --- & 4.9 & 17.9 \\
Achillea millefolium & --- & 38.6 & 41.9 \\
Plantago lanceolata & --- & 21.9 & 54.9 \\
Pimpinella saxifraga & --- & 15.3 & 55.5 \\
Ranunculus acris & --- & 4.7 & 58.6 \\
Alchemilla monticola & --- & 2.6 & 56.3 \\
Leucantemum vulgare & --- & --- & 49.8 \\
Phleum pratense & --- & --- & 55.9 \\
Lotus corniculatus & --- & --- & 59.4 \\
Prunella vulgaris & --- & --- & 61.7 \\
Trifolium pratense & --- & --- & 67.7 \\
Trifolium repens & --- & --- & 68.4 \\
Cynosurus cristatus & --- & --- & 86.8 \\
\hline
\end{tabular}

Table 2. General characteristics of plant communities

\begin{tabular}{|c|c|c|c|}
\hline \multirow[b]{2}{*}{ Parameter } & \multicolumn{3}{|c|}{ Vegetation unit } \\
\hline & $\begin{array}{l}\text { Vaccinium } \\
\text { myrtillus } \\
\text { community }\end{array}$ & $\begin{array}{l}\text { Hieracio- } \\
\text { Nardetum } \\
\text { association }\end{array}$ & $\begin{array}{l}\text { Gladiolo- } \\
\text { Agrostietum } \\
\text { association }\end{array}$ \\
\hline Altitude [m a.s.l.] $* *$ & $881-1064$ & $701-969$ & $663-897$ \\
\hline Slope $\left[^{\circ}\right]$ & $0-25$ & $0-35$ & $5-30$ \\
\hline Ellenberg's indicator values & & & \\
\hline Temperature $[\mathrm{T}] * *$ & 4.7 & 5.3 & 5.3 \\
\hline Moisture $[\mathrm{F}]^{* *}$ & 5.2 & 4.9 & 5.0 \\
\hline Reaction $[\mathrm{R}]^{* *}$ & 3.5 & 4.5 & 5.3 \\
\hline Nutrients $[\mathrm{N}]^{* *}$ & 3.1 & 3.6 & 4.1 \\
\hline Total number of species $* *$ & 48 & 92 & 128 \\
\hline $\begin{array}{l}\text { Mean number of species in } \\
\text { relevé } * *\end{array}$ & 14.1 & 28.8 & 39.0 \\
\hline $\begin{array}{l}\text { Shannon-Wiener diversity } \\
\text { index } * *\end{array}$ & 1.7 & 2.6 & 2.9 \\
\hline
\end{tabular}

** - differences between vegetation units significant at $\mathrm{p}<0.01$ (Kruskal-Wallis test) 
Patches of multi-species Hieracio-Nardetum association are the remains of once dominant in the Beskid Sądecki type of grassland (Pawłowski, 1925). The sward includes a large share of Nardus stricta together with other species characteristic of this association, such as Carex pilulifera, Potentilla erecta and Veronica officinalis. Many species can be found here that are also found in Gladiolo-Agrostietum association. These include Achillea millefolium, Veronica chamaedrys, and Plantago lanceolata. Often, however, the dominant species are Festuca rubra or Agrostis capillaris (Table 1). This community is found at lower altitudes (700-970 $\mathrm{m}$ a.s.1.). The number of species in the phytosociological relevé ranges from 19 to 41 (on average 28.8) (Table 2 ). The community with the greatest species diversity is Gladiolo-Agrostietum association. In the patches of this community 128 plant species were recorded, and in individual relevés from 28 to even 55 species (on average 39). Such meadows are usually found in the lower parts of the massif (600-900 $\mathrm{m}$ a.s.1.) (Table 2). The sward is often dominated by Agrostis capillaris, and the presence of species associated with fertile grassland, such as Dactylis glomerata, Trifolium pratense and Trifolium repens is typical. Sporadic use as pasture is indicated by the small but frequent share of Cynosurus cristatus (Table 1). The indicator values show that the communities do not differ significantly in terms of temperature $(T)$ and moisture $(F)$ requirements. However, substantial differences were noted with respect to soil reaction $(\mathrm{R})$ and nutrients $(\mathrm{N})$, which were highest in the case of the Gladiolo-Agrostietum association, and lowest in the Vaccinium myrtillus community (Table 2). Analysis of the archival maps indicated that most of the 73 phytosociological relevés were situated in sites that had been used as arable land in the mid-nineteenth century and still in the 1930s. Only in the case of one relevé was it found in a location marked as arable land in the 1980s (Table 3).

Table 3. The number of phytosociological relevés on areas with the same type of land use in the past

\begin{tabular}{lccr}
\hline Land use & \multicolumn{3}{c}{ Period of time } \\
& $\begin{array}{c}\text { mid-nineteenth } \\
\text { century }\end{array}$ & $1930 \mathrm{~s}$ & $1980 \mathrm{~s}$ \\
\hline Arable land & 46 & 51 & 1 \\
Grassland & 27 & 22 & 72 \\
\hline
\end{tabular}

The variation in the species composition of communities present in clearings in the Łomniczanka and Wierchomlanka catchment indicate that altitude was a decisive factor. The grasslands analyzed were separated by short distances, but with considerable variation in altitude, up to $400 \mathrm{~m}$. Increasing altitude above sea level was accompanied by a decrease in species variation, expressed both as number of species and the Shannon-Wiener index, and by an increase in the mean indicator value of the plants for nutrients $(\mathrm{N})$ and reaction $(\mathrm{R})$ (Figure $2 B$ ). Due to an autocorrelation between the way of management in the 1930 s and in the mid $-19^{\text {th }}$ century, the analysis took into account only the way of management in the $19^{\text {th }}$ century. The selected variables (altitude, exposure, land use in the past, slope) described $17.58 \%$ of the total variance in species composition. Altitude above sea level was responsible for the largest part of it $-9.86 \%$ and even for $10.29 \%$ after eliminating the influence of the remaining variables (pure effect) (Table 4). 
Table 4. Effect of environmental variables (percentage of explained variation), considered individually (marginal effect) and after deducting the impact of other statistically significant variables (pure effect)

\begin{tabular}{lrrrr}
\hline $\begin{array}{l}\text { Environmental } \\
\text { variables }\end{array}$ & $\begin{array}{c}\text { Marginal } \\
\text { effect }\end{array}$ & $\mathrm{p}$ & $\begin{array}{c}\text { Pure } \\
\text { effect }\end{array}$ & $\mathrm{p}$ \\
\hline Altitude & 9.86 & 0.002 & 10.29 & 0.002 \\
Northness & 2.57 & 0.014 & 2.14 & 0.008 \\
Eastness & 1.72 & 0.028 & 2.14 & 0.018 \\
Land use mid- & 2.14 & 0.032 & 1.72 & 0.028 \\
nineteenth century & & & & \\
Slope & 1.29 & 0.164 & - & \\
Total & 17.58 & & 16.29 & \\
\hline
\end{tabular}

\section{Discussion}

In contrast with our results, many studies on the biodiversity of semi-natural grassland communities have not shown one main factor influencing species composition (Janišová et al., 2010; Pruchniewicz and Żołnierz, 2014). This may be due to differences in the size of the areas studied. The factors determining species composition in a relatively small area may be different than those acting on a larger scale (Vandvik and Birks, 2002). In the catchment of the Łomniczanka and Wierchomlanka Rivers the variation caused by the altitude above sea level was nearly $10 \%$. This is relatively high, considering that in a study on the effect of factors on the formation of grassland communities in Slovakia the total variance explained by all variables together was only $12 \%$ (Klimek et al., 2008). The low percentage of explained variance is typical of data containing many zero values (ter Braak and Verdonschot, 1995), as is usually the case with phytosociological data.

As altitude increased climatic determinants change. The mean air temperature falls by $0.72^{\circ} \mathrm{C} / 100 \mathrm{~m}$ a.s.l., and the length of the growing period in the conditions of Beskidu Sądecki is reduced by 6.2 day per $100 \mathrm{~m}$ a.s.l. (Brzeźniak and Czemerda, 1987), while precipitation increases (Brzeźniak et al., 1984). The indicator values for temperature (T) decreased as altitude increased, but this correlation was weak. This may be due to the relatively low variation in plant species in relation to this factor, as manifested by the large number of species for which no $\mathrm{T}$ values are given. Changes in altitude are also accompanied by changes in soil conditions (Manojlović, 2011) differences occur in particular between locations on the sides of mountains and on their hilltops (Maciaszek, 2000). The substantial effect of altitude is linked not only to a change in climate and soil conditions, but also to the possibility and profitability of agricultural use (Tasser and Tappeiner, 2002). Thus the change from arable land to grassland, and then to abandonment of agricultural practices, occurs first in areas that are the most difficult to access, usually at higher altitudes (Twardy, 2008; Tasser and Tappeiner, 2002). Influence of altitude on biodiversity is of common nature and concerned different groups of organisms (Sergio and Pedrini, 2007). Grasslands as semi-natural communities arose in the place of forest and are dependent on mowing or grazing to stop the succession process (Szydłowska, 2010; Hejcman et al., 2013; Tälle et al., 2015). For their existence, apart from suitable soil and climate conditions, diaspores of grassland species must appear. This takes place mainly through anemochory (Tackenberg et al., 2003) and zoochory (Cosyns et al., 2006; Purschke et 
al., 2014), but in either case it takes time (Hutchings and Booth, 1996). This time period may vary, depending mainly on the distance from the sources of the diaspores. In a traditional, alternating system of grassland management in the mountains, when at regular intervals the grassland was ploughed and after a few years grassland use was resumed, meadows and arable fields were present in a spatial mosaic. The flow of diaspores from the meadows to the arable fields was easy and the newly formed meadows rapidly regained a rich species composition (Włodarczyk, 1956). Similar fast process of species immigration to old fields from nearby grasslands was observed in case of xerothermic vegetation (Woch, 2011). In the case of forest clearings this process may last a long time (Winsa et al., 2015). One factor that may influence species composition on former arable land is cultivation procedures, particularly fertilizers that alter the chemical and physical properties of the soil (Chmolowska et al., 2016). For this reason many studies have found that the species composition of grasslands depends on how long the land has been used as grassland (Pitkänen et al., 2016, Purschke et al., 2014). In mountain grasslands in Norway, Austrheim and Olsson (1995) found that the most rapid and greatest changes in species composition took place over a period of up to 23 years from the abandonment of ploughing. Cartographical data indicate that during the period between the mid-nineteenth century and the 1930s there were no fundamental changes in land use in the study area. Arable land stretched as far as to altitudes above 1,000 m. a.s.l. (Kubijowicz, 1927). Fundamental changes in land use took place later. The very small percentage of variance $(1.72 \%)$ explained by the land management in the past shows that the time elapsed from the transformation of the land into grassland was long enough for typical grassland communities to form. The time needed for the formation of typical grassland communities is highly varied and depends on a number of factors. In the case of xerothermic grasslands the effect of arable land use was demonstrated after more than 100 years (Forey and Dutoit, 2012) while in a study by Chýlová and Münzbergová (2008) the presence of xerothermic communities was noted in places that had been managed in different ways 50 years before. In these studies, however, there was no single factor as strong as altitude above sea level determining the species composition of plant communities. Semi-natural grasslands in a forest zone were created by human activities and their existence depends entirely on their current management (Valkó et al., 2012; Pavlů et al., 2016; Kulik, 2014). Hence, abandonment of farming practices is a more important than the way of land use in the past. HieracioNardetum association which dominated in the upper parts of Polish Carpathians in the past (Korzeniak, 2016) has been replaced by Vaccinium myrtillus community as a stage of succession of unmanaged grasslands.

Species-rich Nardus grasslands (6230 Natura 2000 code) are currently among the most threatened habitats in Poland and Europe (EIONET) and has been considered as a priority habitat in Natura 2000 network (European Commission). The preservation of such high natural value communities requires their mowing or grazing, which is not possible without subsidies under agrienvironmental programs (Jellinek, 2016).

\section{Conclusions}

1. The varied species composition of the grassland communities in the study area was mainly due to the effect of their location at different altitudes above sea level. 
2. The highest species diversity was noted for the Gladiolo-Agrostietum association, situated at low altitudes, and the lowest for the Vaccinium myrtillus community, located in the higher parts of the massif.

3. As the altitude above sea level increased, the fertility and $\mathrm{pH}$ of the soils decreased, expressed as the indicator value of the plant species.

4. The influence of the type of land use in the mid-nineteenth century and the 1930s on the species composition was small. All three types of communities were found in both the fields that had been used as arable land and in those used as grassland in the mid-nineteenth century and the 1930s.

5. None of the plots in the study area (except one) had been ploughed for at least 30 years. This period was sufficient for the formation of grassland communities.

6. The abandonment of plant communities management is one of the most important factors that influenced botanical composition of grasslands.

Acknowledgments. The research was realized within the Project no. DS-3337/KEKiOP financed from the research grant allocated by the Ministry of Science and Higher Education.

\section{REFERENCES}

[1] Austrheim, G, Olsson, EGA. (1995): How does continuity in grassland management after ploughing affect plant community patterns?- Plant Ecol.145: 59-74.

[2] Bielecka, K. (1969): Przemiany struktury użytkowania ziemi w Polsce na przełomie XIX i XX wieku. PWN, Warszawa

[3] Braun-Blanquet, J. (1964): Pflanzensociologie. Grundzüge der Vegetationskunde. 3. Aufl. Springer Verl., Wien, Austria.

[4] Brzeźniak, E., Czemerda, A. (1987): Termiczne uwarunkowania wegetacji roślin uprawnych w Beskidzie Sądeckim.- Probl. Zagosp. Ziem Górskich 28: 59-74.

[5] Brzeźniak, E., Czemerda, A., Fijał, J. (1984): Opady atmosferyczne w Beskidzie Sądeckim.- Probl. Zagosp. Ziem Górskich 25: 7-18.

[6] Bucała, A (2014): The impact of human activities on land use and land cover changes and environmental processes in the Gorce Mountains (Western Polish Carpathians) in the past 50 years. - J. Environ. Manage. 138: 4-14.

[7] Chmolowska, D., Kozak, M., Laskowski, R. (2016): Soil physicochemical properties and floristic composition of two ecosystems differing in plant diversity: fallows and meadows. Plant and Soil 402(1-2): 317-329.

[8] Chýlová, T., Münzbergová, Z. (2008): Past land use co-determines the present distribution of dry grassland plant species. - Preslia 80: 183-198.

[9] Chytrý, M., Dražil, T., Hájek, M., Kalníková, V., Preislerová, J., Šibík, J., Ujházy, K., Axmanová, I., Bernátová, D., Blanár, D., Dančák, M., Dřevojan P., Fajmon, K., Galvánek, D., Hájková, P., Herben, T., Hrivnák, R., Janeček, S., Janišová, M., Jiráská, S., Kliment, J., Kochjarová, J., Lepš, J., Leskovjanská, A., Merunková, K., Mládek, J., Slezák, M., Šeffer, J., Šefferová, V., Škodová, I., Uhlířová, K. J., Ujházyová, M., Vymazalová M., (2015): The most species-rich plant communities in the Czech Republic and Slovakia (with new world records).- Preslia, 87: 217-278.

[10] Cosyns, E., Bossnyt, B., Hoffmann, M., Verraet, H., Lens, L. (2006): Seedling establishment after endozoochory in disturbed and undisturbed grasslands.- Basic Appl. Ecol. 7: 360-369.

[11] Cousins, S. A., Auffret, A. G., Lindgren, J., Tränk, L. (2015): Regional-scale land-cover change during the 20th century and its consequences for biodiversity. - Ambio 44(1): 1727. 
[12] Cousins, S.A.O., Eriksson, O. (2002): The influence of management history and habitat on plant species richness in a rural hemiboreal landscape, Sweden. - Landscape Ecology 17 (6): 517-52.

[13] EIONET. Available online: http://bd.eionet.europa.eu/article17/reports2012/habitat/summary/?period=3\&group=Gras slands\&subject=6230\&region=ALP. (06.03.2017).

[14] Ellenberg, H. jun. (1985): Veraenderungen der Gefaesspflanzenflora Mitteleuropas unter dem Einfluss von Duengung und Immissionen. Schweiz. Forstwes. 136 (1): 19-39.

[15] Ellenberg, H., Weber, H, E., Düll, R., Wirth, V., Werner, W., Paulißen, D. (1992): Zeigerwerte von Pflanzen in Mitteleuropa. - European Commission DG Environment Interpretation manual of European Union habitats - EUR28, 2013.

[16] Forey, E, Dutoit, T. (2012): Vegetation, soils and seed banks of limestone grasslands are still impacted by former cultivation one century after abandonment. - Commun Ecol 13: 194-202.

[17] Hejcman, M., Hejcmanová, P., Pavlů,V., Beneš, J. (2013): Origin and history of grasslands in Central Europe-a review.- Grass Forage Sci. 68: 345-363.

[18] Hutchings, M.J., Booth, K.D. (1996): Studies of the feasibility of re-creating chalk grassland vegetation on ex-arable land. I. The potential roles of the seed bank and seed rain. - J. Appl. Ecol. 33: 1171-1181.

[19] Janišová, M., Uhliarová, E., Hlásny, T., Turisová, I. (2010): Vegetation-environment relationships in grassland communities of central Slovakia.- Tuexenia, 30: 423-443.

[20] Jellinek, S. (2016): Using prioritisation tools to strategically restore vegetation communities in fragmented agricultural landscapes. Ecological Management \& Restoration, 18(1): 45-53.

[21] Klimek, S., Marini, L., Hofmann, M., Isselstein, J. (2008): Additive partitioning of plant diversity with respect to grassland management regime, fertilisation and abiotic factors.Basic and Applied Ecology, 9: 626-634.

[22] Kolecka, N., Kozak, J., Kaim, D., Dobosz, M., Ginzler, C., Psomas, A. (2015): Mapping secondary forest succession on abandoned agricultural land with LiDAR point clouds and terrestrial photography. - Remote Sensing 7(7): 8300-8322.

[23] Korzeniak, J.(2016): Mountain Nardus stricta grasslands as a relic of past farming - the effects of grazing abandonment in relation to elevation and spatial scale.- Folia Geobotanica 51: 93-113.

[24] Kubijowicz, W. (1927): Życie pasterskie w Beskidach Magurskich. Prace Kom. Etnograficznej PAU, Kraków

[25] Kulik, M. (2014): Changes of biodiversity and species composition of Molinia meadow depending on use method. - Pol. J. Environ. Stud. 23 (3): 773-782.

[26] Maciaszek, W. Gleby, in: Przyroda Popradzkiego Parku Narodowego. Popradzki Park Krajobrazowy J. Staszkiewicz (ed.) (2000): 47-56, Nowy Sącz

[27] Manojlović, M., Čabilovski, R., Sitaula, B. (2011): Soil organic carbon in Golija mountain (Serbia) soils: effects of land use and altitude. - Pol J Environ Stud. 20: 977-98.

[28] Matuszkiewicz W., (2011): Przewodnik do oznaczania zbiorowisk roślinnych Polski. WN PWN, Warszawa

[29] Mirek, Z., Piękoś-Mirkowa, H., Zając A., Zając M. (2002): Flowering plants and pteridophytes of Poland. A checklist. Biodiversity of Poland, 1. PAN, Kraków

[30] Morzyniec, W., Piech, I., Goraj, S. (2016): Changes in the landscape and land use in the Pieniny National Park. - Acta Scientiarum Polonorum-Formatio Circumiectus 15 (3): 101-112.

[31] Pavlů, L., Gaisler J., Hejcman, M., Pavlů, V. V. (2016): What is the effect of long-term mulching and traditional cutting regimes on soil and biomass chemical properties, species richness and herbage production in Dactylis glomerata grassland? - Agriculture, Ecosystems \& Environment 217: 13-21. 
[32] Pawłowski, B. (1925): Geobotaniczne stosunki Sądecczyzny. - Prace Monograficzne Komisji Fizjograficznej PAU, Kraków

[33] Pitkänen, T.P., Kumpulainen, J., Lehtinen, J., Sihvonen, M., Käyhkö, N. (2016): Landscape history improves detection of marginal habitats on semi-natural grasslands. Science of the Total Environment 539: 359-369.

[34] Pruchniewicz, D., Żołnierz, L. (2014): The influence of environmental factors and management methods on the vegetation of mesic grasslands in a central European mountain range.- FLORA 209: 687-69.

[35] Purschke, O., Sykes, M. T., Poschlod, P., Michalski, S. G., Rőmermann, C., Durka, W., Kühn, I., Prentice, H. C. (2014): Interactive effects of landscape history and current management on dispersal trait diversity in grassland plant communities. - Journal of Ecology 102: 437-446.

[36] Reitalu, T., Johansson L.J., Sykes, M.T., Hall, K., Prentice, H.C. (2010): History matters: village distances, grazing and grassland species diversity. - Journal of Applied Ecology, 47: 1216-1224.

[37] Roberts, D.W.(1986): Ordination on the basis of fuzzy set theory.- Vegetatio 66: 123-13.

[38] Roleček, J., Tichý, L., Zelený, D., Chytry, M. (2009): Modified TWINSPAN classification in which the hierarchy respects cluster heterogeneity. - Journal of Vegetation Science 20: 596-602.

[39] Schaffers, A. P., Raemakers, I. P., Sýkora, K. V., ter Braak, C. J. F. (2008): Arthropod assemblages are best predicted by plant species composition. - Ecology 89: 782-794.

[40] Sergio, F., Pedrini, P. (2007): Biodiversity gradients in the Alps: the overriding importance of elevation.- Biodivers.- Conserv. 16: 3243-3254.

[41] Shi, K., Imura, O., Morimoto, N., Riordan, P. (2014): Effects of environmental and management factors on the structure of bird communities in the grasslands of northeastern Tochigi, Central Japan. - Grassl. Sci. 60: 45-54.

[42] Siramia, C., Brotonsa, L., Burfielde, I., Fonderflickf, J., Martina, J L. (2008): Island abandonment having an impact on biodiversity? A meta-analytical approach to bird distribution changes in the north-western Mediterranean. - Biological Conservation. 141: 450-459.

[43] Strijker, D. (2005): Marginal lands in Europe - causes of decline.- Basic and Applied Ecology 6: 99-106.

[44] Szydłowska, J. (2010): Charakterystyka florystyczna runi oraz ocena fitoindykacyjna warunków siedliskowych wybranych łąk śródleśnych. - Rocznik Ochrony Środowiska 12: 299-312.

[45] Tackenberg, O., Poschlod, P., Bonn, S. (2003): Assessment of wind dispersal potential in plant species. - Ecological Monographs 73: 191-205.

[46] Tälle, M., Fogelfors H., Westerberg, L., Milberg, P. (2015): The conservation benefit of mowing vs. grazing for management of species-rich grasslands: a multi-site, multi-year field experiment. - Nord. J. Bot. 33: 761-768.

[47] Tasser, E., Tappeiner, U. (2002): Impact of land use changes on mountain vegetation. Appl. Veg Sci. 5: 173-184.

[48] ter Braak, C.J., Verdonschot, P.F. (1995): Canonical correspondence analysis and related multivariate methods in aquatic ecology. - Aquat. Sci. 57: 255-289.

[49] ter Braak, C.J.F., Smilauer, P. (2002): Canoco Reference manual and CanoDraw for Windows users guide: Software for Canonical Community Ordination (version 4.5), Microcomputer Power (Ithaca NY USA).

[50] Tichý, L. (2002): JUICE, software for vegetation classification.- Journal of Vegetation Science 13: 451-453.

[51] Twardy, S. (2008): Karpackie użytki rolne jako obszary o niekorzystnych warunkach gospodarowania (ONW).- Woda Środowisko Obszary Wiejskie, 8,2b (24): 191-202. 
[52] Valkó, O., Török, P., Matus, G., Tóthmérész, B. (2012): Is regular mowing the most appropriate and cost-effective management maintaining diversity and biomass of target forbs in mountain haymeadows? - Flora 207: 303-309.

[53] Vandvik, V., Birks, HJB. (2002): Partitioning floristic variation in Norwegian upland grasslands into within-site and between-site components: are the patterns determined by environment or by land-use? - Pl. Ecol. 162: 233-245.

[54] Wilson, J. B., Peet, R. K., Dengler, J., Pärtel, M. (2012): Plant species richness: the world records - Journal of Vegetation Science 23: 796-802.

[55] Winsa, M., Bommarco, R., Lindborg, R., Marini, L., Öckinger, E. (2015): Recovery of plant diversity in restored semi-natural pastures depends on adjacent land use. - Applied Vegetation Science 18(3): 413-422.

[56] Włodarczyk, S. (1956): Samozadarnianie mieszanek koniczynowych w rejonach górnych upraw w Kościelisku k/Zakopanego. - Rocz. Nauk Rol. 71 F 4: 893-920.

polowych

[57] Woch, M. (2011): Xerothermic vegetation of fallow lands in western Małopolska. - Ann. Univ. M. Curie-Skłodowska, Sect. C 66(1): 105-120. 